
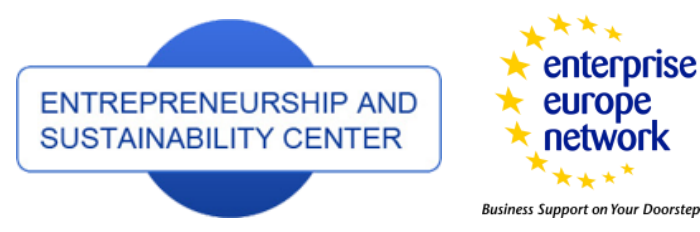

\title{
EFFECTS OF CONTRACTOR AND EMPLOYER'S OBLIGATIONS IN BUY BACK CONTRACTS: CASE STUDY OF OIL EXPORTING COUNTRY*
}

\author{
Farzam Ardalan ${ }^{1}$, Nejad Ali Almasi ${ }^{2}$, Mansour Atasheneh ${ }^{3}$ \\ 1,2,3 Department of Private Law, UAE Branch, Islamic Azad University, Dubai, UAE, \\ Faculty of Law and Political Science, University of Tehran, 16th Azar St., Enghelab Sq., Tehran, 14176-14418, Iran \\ E-mails: ${ }^{1}$ farzamardalan3@ gmail.com; ${ }^{2}$ nejadalialmasia@gmail.com; ${ }^{3}$ mansouratasheneh@ gmail.com
}

Received 20 July 2017; accepted 28 October 2017; published 28 December 2017

\begin{abstract}
Buy back contracts are one of the variety of investment in oil industry in Iran. To put it another way, the main purpose of contracts such as buy back is to increase investment and attract more capital and foreign currency in the country. As it has been proved in economics and business sciences at international level, when investment is made in a country, it directly or indirectly bears positive impacts on all groups of people. The present research study aimed to examine the juridical status of one of the buy back deal sides under the name of contractor, who is supposed to invest and develop oil fields along with other related issues so that topics such as tax payment, insurance, workers, and civil responsibilities of contractors against employer would be more taken into consideration by contractors and more importantly, contractors could know about different insurance coverages and select their intended one and also abdicate any responsibility resulted from legal crimes from themselves by setting tax returns. This, in turn, helps them to do their business activities without any problem in the host country. Furthermore, employers also have some financial and non-financial obligations to contractors including preparing the required conditions for implementation of the deal substances. Knowing about these factors helps the two sides to sign a legal deal. Finally, the present study was an attempt to present a case study, which would raise the two sides' knowledge about their rights and sign the bay back contract according to predetermined specific legal regulation.
\end{abstract}

Keywords: Buy Back Contracts, investment, oil industry, contracts, Iran economic, case study

Reference to this paper should be made as follows: Ardalan, F.; Almasi, N. A.; Atasheneh, M. 2017. Effects of contractor and employer's obligations in buy back contracts: case study of oil exporting country, Entrepreneurship and Sustainability Issues 5(2): 345-356. http://doi.org/10.9770/jesi.2017.5.2(13)

JEL Classifications: K12; F1, F14

Additional disciplines: law

\section{Introduction}

Energy availability is one the facet of energy security, driving force of sustainable economic regional developmet (e.g. Tvaronavičienè et al. 2017; Strielkowski et al. 2016; Melas et al. 2017).

\footnotetext{
* This research was supported Islamic Azad University, UAE Branch
} 
Therefore legal environment in oil exporting countries inevitable obtain increasing importance for interested parties.

Iran has remarkable oil reservoirs in the world and it might be taken as one of the biggest oil tanks countries in the world.

According to an official statistics, Iran has 137.6 billion barrels of oil reserves and this has caused it to be the second-largest oil producer and exporter in the world (the first country is Saudi Arabia). Furthermore, after Russia which is regarded as the largest natural gas producer in the world, Iran has the second position in this term (Ghandi \& Lin, 2011). Iran, as one of the main member countries of Oil Petroleum Explorer Countries (OPEC), has its economy largely on the basis of oil export revenues and it is, in essence, its main source of revenue. (Estelami 1999). However, due to a set of problems inside or outside of the country, the possibility of investment by both Iranian and non-Iranian persons and companies has considerably been decreased. On one hand, there are specific economic policies in Iranian constitution that are big hurdles against foreign investors and do not permit them to easily invest in different stages of discovery, development, or exploitation of oil and gas. This is largely due to the sovereignty issues present in the country's constitutions and petroleum rules (Ghandi \& Lin 2011). On the other hand, there are some sanctions imposed by some powerful governments and countries on Iran that, in turn, prevents the two sides from having a mutual beneficial business.

Sanctions are mainly of two types: trade sanctions and financial ones. The former usually targets a country's import and export capabilities and cause embargoes on traded items and services (Pratt \& Alizadeh 2017). The latter type of sanctions is mostly related to banks, financial institutions, and persons and tries to inhibit any kind of global fiscal trades (Andreasson 2008).

Recently, tougher sanctions have been imposed against Iran with the purpose stopping or reducing the progress of the country's nuclear program. These sanctions targeted a series of economic, scientific and technological, military and strategic actions. The most severe of them were banning any trade and interaction with Iran's Central Bank and also sanctions related to the country's oil trade. These sanctions largely aim to paralyze Iran's oil industry, as its main revenue, and also to reduce the important role of the Central Bank to be active in the selling of oil to the other countries of the world. These sanctions have been referred to as the toughest ones in the history (Sadeghi-Boroujerdi 2012).

The European Union (UN) also boycotted Iran and mostly focused on banks, trade and gas imports of Iran. Assets of persons and factories and organizations that made technology available to Iran were also seized (Pratt \& Alizadeh 2017). The EU has also imposed sanctions on the Central Bank of Iran, its natural gas and metals, and has taken measures to make business trade between Europe and Iran more difficult (Moret 2015).

Many organizations are not willing to be involved in any interaction and trade with Iran due to many complicated barriers against them (for example, their need to gain specific certificates and licenses to sell exempted merchandise such as medicine. Other factors including baffling bureaucracy, long delays in payments also contribute to Iran's economic problems (Erdbrink 2012, Borger and Dehghan 2013). Cargo traffic has also been reported to reduce due to a set of factors such as limitations on Iranian ports and shipping companies such as insurance bans (Heydarian 2012; Moret 2015; Seeberg 2016). Furthermore, high transport costs and the use of middlemen to circumvent probable problems related to sanctions are also other problems that might discourage any company from interaction with the country.

The adoption of service contracts may also affect the ability of host governments to attract investment offered by international oil companies (Ghandi \& Lin 2014). Buy-back service contracts are the basis of Iran's energy 
policies, made by the National Iranian Oil Company (NIOC) (Ghandi \& Lin 2014). These contracts offers tough constitutional rules that restrict foreign oil companies to be involved in the country oil and natural gas works (Ghandi \& Lin 2011) They have also helped the NIOC to make use of the IOCs' technical and fiscal capabilities as the IOC has the responsibility of developing the field (Van Groenendaal \& Mazraati 2006). Although Iran's service contracts are typically referred to as buy-back service contracts, their frameworks present three generations of service-type contracts in the country (Ghandi \& Lin 2014).

Presenting some points concerning the judicial framework of buy back deals and also explaining their legal precepts at international and Iran level, the current study tried to make it possible for the two sides to reach agreement sooner. Furthermore, it helps them to reach unity in setting a deal without any opinion differences. Although any contract and deal depends on specific features and conditions, this study dealt with explaining general precepts of contracts in terms of rights, obligations, decisions, facilities and amenities, technology, and other related issues.

\section{Impacts of Buy Back Contracts on Rights and Obligations of Contractor}

The first buy-back service contract of Iran was signed on March 6, 1995 with Conoco Oil Company Alikhani, 2000) and after that, a set of other contracts were signed (Ghandi \& Lin 2011). A service contract is an almost long time framework governing the interrelationship of a host government and international oil companies (IOCs) in which the IOCs explore oil or natural gas fields for the host government for already determined money. Almost in all of the cases the host government does not permit the IOCs to have any control on the extracted or subsoil or sub-surface resources (Ghandi \& Lin 2011).

The term "contractor" refers to a company - or foreign companies - that signs a deal with National Iranian Oil Company(NIOC) and is supposed to invest, develop the oil fields, develop amenities, etc. in Iran oil upstream section, and national Iranian oil company, as the representative of oil ministry of Iran, is known as the employer of this deal. In the first article of oil rule approved on October, $1^{\text {St }}$, 1987, the term "contract" has been explained as: "contract means obligations made between oil ministry and an operational unit or any real or legal person who takes the responsibility of doing some parts of oil operations in line with Iranian's rules". In continuation, article 3 also states that: "any determination and assignment of the right of ownership and sovereignty of oil amenities and sources belongs to the Islamic government that, according to this rule, should be done by oil ministry".

Buy-back service contract is typically referred to as a contract between the National Iranian Oil Company and an International Oil Company (IOC) by which the IOC is commited to develop an oil or natural gas field and also to deliver the field to the NIOC when production starts.(Ghandi \& Lin 2011)

\section{Contractor's Rights and Obligations}

At first, the rights and obligations of contractor and then those of the employer would be studied.

\subsection{Impact of Buy Back Contracts on Contractor's Rights}

This section deals with the most important fiscal rights effective in contractor's deal:

\section{Receiving Remuneration}

After contractor does all its obligations and NIOC also approves this, the contractor is qualified to receive its remuneration and all costs and invest benefit. The IOC's yearly repayment rates are in accordance with special amounts of the production of the field and an agreed-on rate of return. Remuneration is extra payments for the IOC's services such as carrying on engineering, procurement and construction actions as well as financing the 
project and technology transfer (Ghandi \& Lin 2011) In Iranian buy-back service contracts, Repayment of the project investment along with fiscal costs, remuneration, management fees and benefits are done in a limited time by specific installments based on the income resulted from selling of up to 60 percent of oil and gas produced from the fields developed (Dehkordi, Hamedani 2014). As receiving remuneration is among the contractor's rights, its payment is also among the employer's duties. The amount of repayment is determined at the time of signing the contract and only in cases that the amount of operation and work agreed in the master development plan is increased or decreased; the amount of remuneration might also be increased or decreased accordingly. On the other hand, repayment is on the basis of part of borrowings repaid in by the NIOC and its estimations are in line with an already agreed on fixed oil price and money equivalent of a portion of the produced crude oil for the IOC. Although the contractor might always expect to receive all oil costs and the agreed payment, the contractor's profit is not fixed.

\section{Costs Compensation}

As it was above-mentioned, repayment of all costs spent by the contractor should be done after the beginning of exploitation from maximumly 60 percent of produced oil from the same project. All capital and non-capital costs and also bank, operational, and consultation costs that have been spent by the contractor during the completion of the project and also payments that the contractor spends for income tax should be returned to the contractor during the remaining time of depreciation. Furthermore, all the costs that the contractor pays after beginning of primary production from the first phase of the contract area should be returned to the contractor based on a usual method without any bank cost usually three months after paying the costs. The tax and tolls costs payed by the contractor out of Iran are not included in this repayment by Iran. As it was already pointed out, repayment of all costs should be done only by selling a specific amount $(60 \%)$ of oil from the same source by Iranian oil company.

\section{Investment benefit}

In addition to remuneration and contracting costs, the investment benefit should also be payed to the contractor. The rate of fiscal facilities benefit is determined in line with the rate acceptable for central bank of the country for other financial facilities (Dehkordi, Hamedani 2014). In each period, any amount of oil costs that is not payed is transferred to next period and in this case, the benefit rate is based on London Inter Bank Offer Rate (LIBOR) along with a higher percentage that is considered for the belated sections of costs. Therefore, it might be stated that the whole income of the contractor involves the repayment of all costs to the pre-determined limit along with compensation money and costs of fiscal supply during the period of loan depreciation. Hence, the contractor can ensure that all oil costs and compensation money are repaid in line with day value. It was often thought that the benefit rate of buy back contracts is fixed. But it is not necessarily this as the repayment of contractor's commission for the purpose of keeping a fixed benefit rate is not eternally set; but, all repayments are done based on day pecuniary conditions and only remuneration is determined at the time of contracting. Therefore, the rate of invest return is not predictable in these types of contracts.

\section{Suitable Reward}

According to one precept of buy-back service contracts, when production on the fields of the contract begins, the NIOC takes over the operation of the field (Van Groenendaal \& Mazraati 2006) meaning that besides ownership rights of the produced crude, and in sharp contrast to production sharing agreements, the NIOC is the operator of the developed fields in the buy-back framework.(Ghandi \& Lin 2011) In other words, Unlike the production sharing contracts in which foreign contractor considers itself as a partner in the field and its resulted productions and as a result, has more motivation to reach the highest possible economic rate by using advanced technology, technical knowledge, skills, amenities, machineries, and raw materials, in buy back contracts, the main preoccupation and concern of the contractor is reaching a specific rate of product in line with the contract. Thus, in these types of contracts, the contractor has no motivation to make use of advanced technology for further production or reducing costs. As a consequence, to motivate contractors in these contracts, other strategies such as 
determining reward payment or prize have been specified. To put it another way, there is always a condition stipulated in the contracts that " if the contractor does its duties correctly and appropriately and the amount of capital costs expenditures do not exceed the capital cost ceiling (CCC), three months earlier than the repayment of costs is finished, contractor and N.I.O.C will adjust the reward and remuneration amount in a way that the investment the rate of return does not exceed x percent for example, $14 \% "$ (Dehkordi, Hamedani 2014). Thus, if capital cost expenditures are less than that specified in the contract, reward will be awarded to the contractor. However, if in contrast, the capital cost expenditures go beyond the pre-determined amount in the contract, this extra cost is not paid by the national Iranian oil company.

\section{Security Right}

One of the rights that each investor (foreign or Iranian) should have is full security especially economically and financially. Security in the country is among the most important and influential factors in attraction of foreign investment. When an investor does not see his investment safe and sure, never risks as he is looking for benefit and therefore, never invests in a risky country with no or less security. The concept of security is wide and involves different economic, life, political, and other security aspects. A foreign investor in a buy back contract is supposed to keep all his amenities, machineries, factories, internal and foreign workers, etc. to the end of projects and their delivery to national Iranian oil company. Health and appropriate keeping of them is depended on security that is among the first human rights. Accordingly, from among duties of oil ministry that has also been stipulated in oil rule of 1987, article 10 is "providing a good and safe condition and environment to encourage and attract efficient committed and expert elements".

\subsection{Impact of Buy Back Contracts on Contractor's Obligations}

After dealing with the rights of contractors, this section touches on their obligations.

\section{Observing the Employer Country Rules}

Contractors are supposed to follow and obey all rules of Iran (as the employer country) from beginning of their operations in projects to the end of projects and delivering them. This obligation has been stipulated in article 120 of work rule approved in 1989: "Alien persons cannot work in Iran unless they have visa with specific work right and also receive related work license based on pertinent rules and regulations". Article 124 of the same rule also states that "work license is issued or renewed or extended for one year maximumly". In order to be in accordance with Iranian rules, contractors are obliged to establish an office in Iran whose related explanations are discussed in the following sections.

\section{Observing International Standards}

From among other duties of contractors is regarding international standards in all their operation stages (Dehkordi, Hamedani 2014). According to Iran's buy-back service contracts, the host government gives no control on extracted or subsoil or sub-surface resources to the IOCs (International Oil Company). In other words, service contracts do not have a profit sharing mechanism (Ghandi \& Lin 2011) So, Contractors usually try to make use of non-standard strategies and methods to finish the projects sooner and this is, in fact, one of defects of buy back contracts in comparison with participation in production ones. Furthermore, since national Iranian oil company has the responsibility of supervising and managing all actions of contractors, they should consider this important point carefully. To do this, contractors should use all their facilities and amenities based on international standards so that the costs related to projects do not exceed what is mentioned in contracts and even become less than it. This observation of international standards should be done by contractors in all stages of the projects. As an example, contractors should do their best to take care of environment and not to damage the area and oil fields. It goes without saying that as more advanced international standards are used, the field would have longer life time and more productivity. 


\section{Using Internal Forces}

NIOC, as a governmental company, is responsible for meeting the purposes of Iranian government economically and non-economically. An important non-economic purpose that NIOC follows is to keep a high employment proportiom of Iranian nations (Ghandi \& Lin 2011).Therefore, in Iran's bay-back service contract, the contractors is obliged to prefer Iranian citizens to non-Iranian ones in their employment for different section of projects and make use of foreign forces only when there is no qualified Iranian force. Foreign writers and researchers regard this as one of articles of Iranian model of buy back contract. One of important responsibilities of oil ministry is preparing and equipping needed work force and this is accomplished only by cooperation and participation of Iranian and foreign forces and using foreign experiences. In article 10 of oil rule approved in 1987 it has been stipulated that "oil ministry is obliged to work for bringing up and equipping needed work force and accessing advanced technology and also developing in different related fields of studies and takes appropriate measures to increase the knowledge and information level of experts and employees. Thus, one of required ways and effective measures is contractor's use of Iranian forces and equipping them with modern knowledge and skill. Maximum use of internal forces' technical and administrative capabilities is an effective way to prevent any transfer of foreign currency from the country.

\section{Training and Transferring Technology and Guaranteeing Efficiency}

It appears that Iran's interest in buy-back service contracts could be accounted for by the requirement for international oil companies' capital. To put it another way, besides the requirement for IOC's capital, the cooperation of the IOC's helps the government to make use of its know-how that, in turn, might consists of project management in different aspects such as how the capital is invested (Ghandi \& Lin 2011).

As a consequence, in Iran's bay back service contracts, Contractors are obliged to make use of Iranian forces as much as possible. In line with this, they are supposed not only employ internal forces in their projects, but also, train them and transfer the needed technologies to Iran. Unfortunately, in most of the contracts that are signed between Iranian officials and foreign sides (in all cases including oil and non-oil ones), it is the product that is transferred to country and not related technologies. Due to a set of factors such as shortage of investment in the country, lack of required skills, shortage of technical knowledge and facilities (technology) for discovery, one of national Iranian oil company preoccupations have always been transferring suitable technical knowledge and also training and equipping internal forces by foreign contractors. There is no exact statistics about how the company has achieved such a purpose. In articles 1 and 10 of oil rule approved in 1987, issues such as training and preparing required work force, developing technology, and elevating industrial and technical knowledge have been predicted. However, unlike oil rule approved in 1974, the strategies and methods for achieving these purposes have not been explained that, in turn, indicates the retrogressive movement of rule maker.

\section{Fiscal Supply of Projects}

Any current cost, tax, tolls, and social security and income tax costs should be paid by foreign contractors and national Iranian oil company repay these costs to them later. The project finance is a contract according to which a bank or commercial institution or a foreign oil company pays a loan to the oil field owner country for a specific operation but has no control on type of spending and at the same time, has no commitment for achieving the operation and just receive the main amount of the loan along with its benefit rate from the guaranteeing government or bank.

Irans's buy back service contracts typically lack Iran's Central Bank guarantee on repayments to IOCs. This is a feature of Iran's second type of buy-back service contract compared to the first version (Shiravi \& Ebrahimi, 2006). According to an official statistics issaed by the International Energy Agency IEA, there is salient increase in the world oil demands from the present level of 84.6 million barrels each day to 105.2 million barrels each day in 2030 (International Energy Agency 2009). This requirement, in turn, needs remarkable investment in oil production and transport infrastructure. Moreover, most of these investments and development would be in OPEC countries. OPEC's enhancing portion of production enhances the significance of comprehending production 
decisions and OPEC countries' energy policies (Ghandi \& Lin 2011). In the fourth program of economic, social, and cultural development, in article 14, section (a) it has been stated that " to increase the capacity of production and keep and elevate the portion of Iran in OPEC production and also to encourage and support attraction of foreign investment and sources in upstream activities of gas and oil, the national Iran oil company is given this permission to act for signing discovery and development of oil fields contracts with foreign companies". Additionally, in the budget rule of 2006, the permission of signing finance contracts and also turning these contracts into buy back ones was given. However, the important point is that in the buy back contracts, national Iranian oil company, as the employer side of the contracts, does not take any commitment and responsibility and the foreign contractor should finance all related costs of projects from the beginning to the end of the operation from international organizations and institutions and as it was already mentioned, guaranteeing these loans is also on contractors' shoulders. The contractor should prepare and pay all oil costs during the discovery or development operations and these costs include all invest, non-invest, operational, and fiscal costs and after the completion of the project, these costs would be repaid to the contractors by N.I.O.C.

\section{Tax Commitments and Work Obligations (Legal)}

This issue is explained and discussed under to paragraphs:

A) As it was already stated, at the beginning, all costs including non-investment ones such as tax, social security, etc. are to be paid by contractors and at the end of the work, these costs are repaid by the employer. Thus, it should be examined how tax is paid by contractors in terms of Iranian rules. As we know, there are two types of tax: one is tax on benefit and income and the other is income tax that includes all employees and personnel working in the contractor company in Iran. The latter type is received from the personnel themselves based on Iranian tax public regulations. Note 20 of article 105 of direct tax rule (amendment approved 2001/02/27) states that "foreign real persons are to pay tax for $25 \%$ of all their obtained income including exploitation of capital in Iran, activities that are done directly by themselves or indirectly by their related representatives and companies or income they might obtain by transferring their rights to others, transferring technical knowledge, and also technical training and helps". However, as it was already mentioned, according to Iran's model of buy back contracts, all costs including tax ones should be paid by contractors at the beginning of projects. Therefore, it might be stated that contractor's tax is paid either directly by national Iranian oil company or they themselves pay them. Those contractors who prepare and purchase all or some of needed pieces and facilities inside the country, are exempted from paying tax to the extent of their purchase (note 2 of article 106 of direct tax rule, amendment 2001).

B) Observing Work Law Rules; One point that contractors are obliged to follow is different working obligations stipulated in related rules and regulations for foreign contractors. As an example, article 120 of work rule states that "alien persons cannot work in Iran unless firstly, they have visa with specific work right and secondly, they receive work license according to related rules". It has also been mentioned in article 124 of the same rule that "work license is issued or extended only for one year maximumly". Therefore, contractors should notice this rule for their foreign workers and employees. Furthermore, contractors are responsible for receiving permission of stay and work for their foreign personnel. Some foreign analysts know this as one limitation of foreign investment in Iran.

In article 20 of encouraging and supporting foreign investors rule (approved in 2002), it has been mentioned that "related executive organizations are supposed to act as to interactive commitments for visa, stay permission, work license, and employment license for foreign managers and experts.

\section{Establishing Representative Office in Employer Country}

In 1998, a single article was approved in Islamic Consultative Assembly under the name of "Permission rule of establishing foreign branch or representative" according to which" foreign companies that are legal companies in their registry place are allowed to establish a branch or representative office in line with the country regulations and rules". The note of executive regulation of the rule, on suggestion of ministry of economics, would be approved by ministers' cabinet and in cooperation with other pertinent organizations. Article 2 of the regulation 
approved in 1999 states that "the branch of foreign companies is under the management of main company and achieves the purposes and actions of the main company in the country and therefore, the responsibility of the branch is with the main company". All companies that are formed and established in buy back contracts are no exception to this rule. Contractors who are obliged to obey all Iran's rules is supposed to follow this rule as well by establishing a branch and doing all related activities by this office.

\section{Keeping Accounting Reports}

Since national Iran oil company has the right of inspecting, accounting, approving, and confirming all spent costs of projects, contractors are obliged to prepare and keep all costs notes and accounts based on commonly accepted accounting methods and examining these accounts by national Iran oil company is possible only by establishing an office.

\section{Offering Report to Employer}

Contractors are obliged to report to the employer (national Iran oil company) concerning all activities that they do especially those related to costs, documents, and accounting deeds. As with accounting, it should be pointed out that announcement of costs, credits, and accounts along with their related documents should be offered to the employer in annual or three-month tables. The employer has the right of appointing its own accountants or Iranian and foreign accountants for examining all related documents, costs, invoices, and deeds of the contractor. It also has the right to have full access to invoices, documents, reports, and any other dependent contractors within working hours.

\section{Completing Tax Return and Tax Acknowledgement}

As it was already explained, according to note 2 of article 105 of direct tax act approved in 2001, foreign companies are to pay a tax for about 25 percent of their total income. Therefore, contractors are obliged to fill in tax returns and pay their related tax and this is done by their representative office established in the country. However, as it was already mentioned, national Iran oil company would repay these costs at the end of projects.

\section{Responsibility Insurance}

Contractors are obliged to insure their personnel, facilities, and tools based on Iran's rules. None of the contract sides is responsible for any direct or indirect damage of the other side. Thus, contractors should insure all his personnel and tools and machineries appropriately and time of the insurance is to the end of projects and their delivery to national Iran oil company.

\section{Impacts of Buy Back Contracts on Employer's Rights and Commitments}

This section deals with rights and commitments of the employer (national Iran oil company) in buy back contracts.

\subsection{Impacts of Buy Back Contracts on Employer's Rights}

Rights of national Iran oil company, as the employer of buy back contracts, are divided into two fiscal and nonfiscal parts.

\section{Fiscal Rights}

Fiscal rights refer to rights that have fiscal and economic values and might be changed into money. Right of contract annulment, obligation right, and right of asking for damage compensation are among the employer's fiscal rights that are to be examined here. In the case where a buy back contractor does not do his duties, national Iran oil company has the right of contract annulment. However, as we know, a set of rights and duties are made for each of the sides of contract and when each of the sides breaches his own obligations, the other side might ask 
for annulment. As with buy back contracts, as the duties of contractors are by far more than those of the employers and contractors are more likely to breach the commitments, the right of annulment in the employer's section is discussed.

\section{Right of Commitment Performing}

In internal Iranian rights, when a committed person does not achieve his obligations, at first, is forced to do commitments and in case of preventing from doing commitments again, the other side of the contract has the right of asking for annulment. This applies for buy back contracts as well. To put it another way, when one of the sides (contractor or employer) prevents from doing his obligations, the other side has annulment right. That is why, as it was already mentioned, when one side does not do his commitments (often contractor side as he has many obligations to do) and this lack of commitment achievement continues after the determined deadline, the annulment right is made for the other side. This deadline is, in fact, a kind of compulsion for the side to do his duties in the specified deadline (usually 90 days in Iran) and after this time, if he does not do his duties again, the right of annulment is created for other side.

\section{Right of Asking for Damage Compensation}

This right does not belong merely to employer. Rather, contractors also might ask for such a right when the employer ignores obligations. As an example, if contractors do not use the required standards for implementation of projects and this leads to damages to the employer, contractors are certainly responsible for compensation of damages. It should, however, be mentioned that when any damage is made for the other side as a result of ignoring the contract and no implementation and compensation guarantee has been predicted in the contract, the culpable side might be obliged to compensate damages according to The rule named as justification rule. In this case, any side that asks for damage compensation, should prove his damage. In other words, three elements are necessary for any realization of responsibility: damage, commitment of damaging action, and causative relationship between action and damage. Thus, if the employer claims damage, should ask for compensation by raising a civil responsibility based on above-mentioned conditions and the same point applies for contractors. Another point to mention is that contractors usually insure themselves for any responsibility against the employer and this is, in fact, a preventive measure against damage.

\section{Non-Fiscal Rights}

Non-fiscal rights refer to those rights that cannot be changed into money even if they have fiscal effects but these fiscal effects are not basic and original.

\section{Inspection and Supervision Right}

Employer has the right of inspection and supervision in coordination with the other side during the project stages. National Iran oil company usually keep the right of inspection for itself in all contracts with contractors. Therefore, the company can inspect different stages of projects such as studying and examining vibrations, excavations, etc. Contractors are committed to offer the related tables and information to the employer's side.

\section{Right of Insurance Coverage Selection}

From among other non-fiscal rights that are typically predicted in Iran's buy back contracts is that of selecting insurance coverage for contractors. It was already explained that one of their duties are to put in priority employing Iranian employees and training them.

\section{Right of Supervising Employees' Training}

Another non-fiscal right is that of supervising trainings that are given to Iranian employees by contractors so that the employer might ensure about the quality of trainings.

\subsection{Impact of Buy Back Contracts, Employer's Obligations}


ENTREPRENEURSHIP AND SUSTAINABILITY ISSUES

ISSN 2345-0282 (online) http://jssidoi.org/jesi/

2017 Volume 5 Number 2 (December)

http://doi.org/10.9770/jesi.2017.5.2(13)

This section deals with the employer's obligations (national Iran oil company) against contractors. These obligations are also divided into fiscal and non-fiscal ones.

\section{Fiscal Obligations}

The most important financial obligations of N.I.O.C. as the employer side of buy back contracts are:

Payment of Costs to Contractors

As it was already explained, at the beginning of the project of developing oil fields, all related costs of projects to the end of them are on contractors' shoulders. However, after the projects are delivered to N.I.O.C., the company is obliged to repay all these costs to contractors.

Export Obligations

As it was stated, the employer is committed to pay all capital, non-capital, remuneration, and benefit costs of contractors in monthly installments from productions of the same project and as it was several times mentioned, money payment has no place in buy back contracts. Rather, to 60 percent of produced gas or oil from the same project is usually paid to the contractor according to a long-term contract. Therefore, the company is supposed to guarantee this payment to the contractor side.

\section{Non-Fiscal Commitments}

To achieve intended purposes in on time beginning of projects and implementation of contract, the employer has a set of non-fiscal commitments as well as fiscal ones against the contractor side including preparing necessary conditions for the work. Furthermore, the employer is supposed to provide other conditions and factors such as land, water, road, etc. for implementing development operations; and also related technical information and authorizations, related customs authorizations for entering and exiting required facilities and machineries.

\section{Conclusions}

What might be concluded from the present research study is that the contract side companies that attend Iran for discovery and development of oil fields projects become familiar with framework of buy back contracts in Iran and might become familiar with their obligations including using human forces and their training and also insurance rules of the country. By knowing about these rules and standards, they would be able to do their work in the country more appropriately and without any legal problem.

\section{Acknowledgement}

We should thank Islamic Azad University, UAE Branch for their support regarding the present research. I do really appreciate their cooperation

\section{References}

Alikhani, H. 2000. Sanctioning Iran: anatomy of a failed policy. London, I.B. Tauris, 352 p.

Andreasson, G. 2008. Evaluating the effects of economic sanctions against Burma http://lup.lub.lu.se/luur/download?func=downloadFile\&recordOId=1335119\&fileOId=1646821

Borger, J. and Dehghan, S.K., 2013. Iran unable to get life-saving drugs due to international sanctions. The Guardian http://www.guardian.co.uk/world/2013/jan/13/iran-lifesaving-drugs-international-sanctions

Dehkordi, P. A.; Hamedani, A. E. 2014. Strategies for foreign investment in Iran's upstream oil industry with an emphasis on Production Sharing Contracts, Asian Journal of Research in Banking and Finance 4(12): 134-139. https://doi.org/10.5958/2249-7323.2014.01459.X 
ENTREPRENEURSHIP AND SUSTAINABILITY ISSUES

ISSN 2345-0282 (online) http://jssidoi.org/jesi/

2017 Volume 5 Number 2 (December)

http://doi.org/10.9770/jesi.2017.5.2(13)

Erdbrink, T., 2012. Iran sanctions take unexpected toll on medical imports. New York Times, 2 November, p.4. http://www.nytimes.com/2012/11/03/world/middleeast/iran-sanctions-take-toll-on-medical-imports.html

Estelami, H. 1999. A Study of Iran's Responses to US Economic Sanctions, Middle East 3(3) http://www.rubincenter.org/1999/09/estelami-1999-09-05/

Ghandi, A., \& Lin, C. Y. C. 2011. Do Iran's Buy-Back Service Contracts Lead to Optimal Production? The Case of Soroosh and Nowrooz https://pdfs.semanticscholar.org/9fb0/7340399d93cd35579fef08c99a0e0a968625.pdf

Ghandi, A., \& Lin, C. Y. C. 2014. Oil and gas service contracts around the world: a review, Energy Strategy Reviews 3; 63-71. https://myassignmenthelp.com/free-samples/oil-and-gas-service-contracts-around-the-world

Heydarian, R.J., 2012. Iran sanctions: collective punishment. Huffington Post, 30 October, p. 2. https://www.huffingtonpost.com/richardjavad-heydarian/iran-sanctions-collective_b_2008211.html

International Energy Agency. 2009. World Energy Outlook 2009. Organisation for Economic Co-operation and Development OECD. http://www.worldenergyoutlook.org/media/weowebsite/2009/WEO2009.pdf

Melas, V.; Lisin, E.; Tvaronavičienè, M.; Peresadko, G.; Radwański, R. 2017. Energy security and economic development: renewables and the integration of energy systems, Journal of Security and Sustainability Issues 7(1): 133-139. https://doi.org/10.9770/jssi.2017.7.1(11)

Moret, E. S. 2015. Humanitarian impacts of economic sanctions on Iran and Syria, European Security 24(1): 120-140. http://www.tandfonline.com/doi/abs/10.1080/09662839.2014.893427

Pratt, S., \& Alizadeh, V. 2017. The economic impact of the lifting of sanctions on tourism in Iran: a computable general equilibrium analysis, Current Issues in Tourism 1-18. http://www.tandfonline.com/doi/abs/10.1080/13683500.2017.1307329

Sadeghi-Boroujerdi, $\quad$ E. 2012. Sanctioning Iran: $\quad$ Implications and http://www.oxfordresearchgroup.org.uk/publications/briefing_papers_and_reports/sanctioning_iran_implications_and_consequences

Seeberg, P. 2016. The EU and the international sanctions against Iran: European and Iranian foreign and security policy interests, and a changing Middle East, Palgrave Communications 2, article number 16080, https://doi.org/10.1057/palcomms.2016.80

Shiravi, A., \& Ebrahimi, S.N. 2006. Exploration and development of Iran's oilfields through buyback, Natural Resources Forum 30 (3): 199-206. https://doi.org/10.1111/j.1477-8947.2006.00114.x

Strielkowski, W.; Lisin, E.; Tvaronavičienè, M. 2016. Towards energy security: sustainable development of electrical energy storage, Journal of Security and Sustainability Issues 6(2): 43-52. http://dx.doi.org/10.9770/jssi.2016.6.2(4)

Tvaronavičienė, M.; Nesterova, K.; Kováčik, V. 2017. Energy security and long-term energy efficiency: case of selected counties, Journal of Security and Sustainability Issues 7(2): 349-357. https://doi.org/https://doi.org/10.9770/jssi.2017.7.2(14)

Van Groenendaal, W.J.H., \& Mazraati, M. 2006. A critical review of Iran's buyback contracts, Energy Policy 34(18): 3709-3718. https://doi.org/10.1016/j.enpol.2005.08.011 
ENTREPRENEURSHIP AND SUSTAINABILITY ISSUES

ISSN 2345-0282 (online) http://jssidoi.org/jesi/

2017 Volume 5 Number 2 (December)

http://doi.org/10.9770/jesi.2017.5.2(13)

Farzam ARDALAN - Ph.D. Candidate of Private Law, Department of Private Law, UAE Branch, Islamic Azad University, Dubai, UAE Tell: +1 6504417671

Nejad Ali ALMASI - Full Professor, Department of Private Law, UAE Branch, Islamic Azad University, Dubai, UAE Tell: +98 2161112532

ORCID ID: https://orcid.org/0000-0001-8726-3329

Mansour ATASHENEH - Assistant Professor, Department of Private Law, UAE Branch, Islamic Azad University, Dubai, UAE Tell: +986133730576

Copyright (C) 2017 by author(s) and VsI Entrepreneurship and Sustainability Center This work is licensed under the Creative Commons Attribution International License (CC BY).

http://creativecommons.org/licenses/by/4.0/

(c) (i) Open Access 